Article

\title{
Centrality of Religiosity Scale in Polish Research: A Curvilinear Mechanism that Explains the Categories of Centrality of Religiosity
}

\author{
Beata Zarzycka *(1), Rafał P. Bartczuk $(1)$ and Radosław Rybarski \\ Institute of Psychology, The John Paul II Catholic University of Lublin, 20-950 Lublin, Poland; \\ bartczuk@kul.pl (R.P.B.); radekrybarski@kul.lublin.pl (R.R.) \\ * Correspondence: zarzycka@kul.pl; Tel.: +48-81-445-3444
}

Received: 27 December 2019; Accepted: 26 January 2020; Published: 29 January 2020

check for updates

\begin{abstract}
The centrality of religiosity scale (CRS) is a measure of the importance of religious constructs in personality. The Polish CRS has been applied in more than 40 published studies on the psychology of religion, with over 18,000 total participants. However, no comprehensive overview on the Polish CRS is available. This paper shows how using the CRS sheds light on different patterns in which religion integrates with other psychological variables. It consists of three parts: first, we introduce the Polish adaptation of the CRS; second, we present the review of the research using the Polish CRS; and finally, we provide research results that suggest a curvilinear mechanism for explaining the categories of the centrality of religiosity. Three measures were applied to the research: the CRS, emotions toward God scale, and content of prayer scale-revised. The results indicated that there is a curvilinear relationship between centrality of religiosity and emotions toward God, prayer types, and styles of request prayer (excluding passive request prayer). We determined the changepoints at which the relationship between the centrality of religiosity and the religious contents changes. This finding allowed us to provide empirical confirmation of Huber's thesis (2003) that there is a different way of operating low, medium, and high scores in centrality, namely marginal, subordinated, and central religiosity. The study also broadens our understanding of each of these types of religiosity.
\end{abstract}

Keywords: centrality of religiosity; religious emotions; prayer; measurement; curvilinearity

\section{Introduction}

The centrality of religiosity scale (CRS) is a measure of the importance of the religious constructs in personality. It has been developed by Stefan Huber and adapted into Polish by Beata Zarzycka $(2007,2011)$. The CRS is a part of the religiosity structure test (RST), a multidimensional tool to measure the importance and contents of the religious construct system in followers of theistic religions (Huber 2006). The basic structure of the RST comprises five dimensions of religiosity distinguished by Stark and Glock (1970): the intellectual, the ideological, the experiential, and public and private practice. The single five-dimensional scale, CRS, was developed to measure the importance of religiosity, whereas various measures of specific contents of religiosity were developed to measure them. The RST subscales are presented in Table 1.

One of the main aims of the CRS development was to measure the position of religious constructs among other constructs in personality, according to the personal construct theory (Huber 2003; Kelly 1955). Individuals with higher scores on the CRS have a more central religious construct system. The validity of this measurement strategy was confirmed empirically in two ways (Huber and Huber 2012). First, high correlations between the CRS and self-reports of the salience of the religious identity, which have traditionally been applied as one item scale, were provided. Second, differential predictions for 
categorical groups of respondents based on their CRS score were tested. Huber (2003) distinguished among the groups: the highly religious with a central position of the religious construct system, the religious with a subordinated position of the personal religious construct system, and the non-religious with a marginal position of the religious construct system ("hardly any religious construct-system exists"; Huber 2007, p. 220). Given that the item scores are one to five, the following thresholds for the categorization of the groups were proposed: 5.0 to 4.0 (central), 3.9 to 2.1 (subordinated), and 2.0 to 1.0 (marginal; Huber and Huber 2012). According to personal construct theory, if the personal religious construct system is in a central position in one's personality, it is hardly restricted by super-ordinate construct systems; it alone can influence the importance, intensity, and frequency of manifestation of the five dimensions of religiosity. If the religious construct system is placed in a subordinate position, its functioning is restricted through many other super-ordinate construct systems. The activation of the five dimensions of religiosity is therefore not under the sole control of the religious construct system; rather, it is under the control of alternating non-religious construct systems. This fact should lead to a different set of values in the five dimensions because each individual dimension might be influenced by another super-ordinate construct system. If the personal religious construct system is in a marginal position in one's personality, most of the dimensions should be consistently low (Huber 2004).

Table 1. The Religious Structure Test subscales.

\begin{tabular}{ccc}
\hline \multirow{2}{*}{ Basic Dimensions } & \multicolumn{2}{c}{ Factors } \\
\cline { 2 - 3 } Intellectual & Centrality of Religiosity Scale (CRS) & Contents (Content Scales) \\
\hline Ideological & Intellect & $\begin{array}{c}\text { Religious reflexivity } \\
\text { Religious quest }\end{array}$ \\
\hline Private practice & Private practice & $\begin{array}{c}\text { God image } \\
\text { Religious pluralisms } \\
\text { Religious fundamentalism } \\
\text { Theodicy }\end{array}$ \\
\hline Religious Experience & Religious experience & $\begin{array}{c}\text { Contents of prayer * } \\
\text { Religious coping styles * }\end{array}$ \\
\hline Public practice & Public practice & $\begin{array}{c}\text { Emotions toward God * } \\
\text { Contents of religious experience }\end{array}$ \\
\hline
\end{tabular}

Note: constructs used in the present study are marked with an asterisk $\left(^{*}\right)$.

Huber and Huber (2012) distinguished and empirically confirmed two constitutive features to differentiate groups with different religiosity status in the personal construct systems. First, the system of personal religious constructs is much more differentiated in a group with a central position of the religious construct system compared to the groups with a subordinated and marginal position in that system. This thesis was confirmed in relation to the theological complexity of positive and negative emotions toward God (Huber 2008b). Second, religious contents, which are salient in the religious construct system of the group with a central position of this system, had a much stronger relevance for general psychological dispositions. This thesis was confirmed with regards to the political relevance of religious concepts (Huber 2008b, 2009) and in relation to the social relevance of the experience of forgiveness by God (Huber et al. 2011). Our predictions go even further. We expected that the status of religious constructs in personality will moderate the relationships between the centrality of religiosity and various religious contents (and presumably with other psychological variables). The present paper aims to provide an empirical confirmation of this prediction.

The article consists of three parts: first, we introduce the Polish adaptation of the CRS; next, we present the review of research using the Polish CRS; finally, we provide research in which we test the curvilinear relationship between centrality and the content of prayer, styles of religious coping, and 
emotions toward God. Furthermore, we attempt to determine on this basis the boundary values of CRS scores for marginal, subordinate, and central religiosity.

\subsection{The Polish Adaptation of the CRS}

The 15-item version of CRS was adapted for Poland. The process of adapting the CRS into Polish was conducted in accordance with the guidelines of the International Test Commission (Hambleton 2001), using the translation procedure (i.e., true translation-with the possibility of introducing necessary modifications when the language specificity of the original scale would cause non-equivalence for the Polish scale (Drwal et al. 1995)). The process of the Polish adaptation of the CRS included two stages. The first stage involved establishing the internal structure, discriminative power of items, reliability, and validity of the CRS. The second stage comprised of re-validating the scale and developing norms for the total score.

The first stage of the adaptation process was performed from 2005 to 2006 . From a total of 462 adults, 231 women and 231 men aged between 22 and $25(\mathrm{M}=23.03, \mathrm{SD}=2.14$ years $)$ participated in the research. A principal component analysis (PCA) with a promax rotation confirmed the CRS structure; the five factors accounted for $79.84 \%$ of the variance. The amount of variance explained by individual factors were as follows: ideology $(53.9 \%)$, religious experience $(8.97 \%)$, intellect $(7.1 \%)$, public practice $(5.66 \%)$, and private practice $(4.16 \%)$. The discriminative power, calculated by means of Yule's point-biserial correlation coefficient, was high between items (from 0.70 to 0.92). The CRS reliability, calculated by means of Cronbach's $\alpha$, was 0.93 on centrality and from 0.82 (intellect and public practice) to 0.90 (ideology) on the subscales. The test-retest stability, with an interval of four weeks, ranged from 0.62 (experience) to 0.84 (public practice), with a total score stability of 0.85 . The CRS validity was examined by correlating the score with the results of other scales that measure religiosity: the centrality of religious attitude scale (Szymołon and Bartczuk 2011), the lived relations to God scale (Hutsebaut 1980; Śliwak and Bartczuk 2011a), the intensity of religious attitude scale (Śliwak and Bartczuk 2011a), the religious crisis scale (Nowosielski and Bartczuk 2011), and the post-critical belief scale (Bartczuk et al. 2011, 2013). The obtained correlation patterns confirmed the CRS validity. Centrality positively correlated with other measure of centrality and the scales measuring positive attitudes to religiosity, namely symbolic and literal inclusion of transcendence, intensity of religious attitude, as well as positive relations with God: identification with God, co-humanity, and acceptance of ethical norms. Negative correlations of centrality referred to the measures of negative religious aspects: religious crisis (Nowosielski and Bartczuk 2011), religious doubts, religious guilt, autonomous and rebellious relations with God, (Śliwak and Bartczuk 2011b), and literal and symbolic exclusion of transcendence (Bartczuk et al. 2011, 2013). The analysis of the CRS validity suggested that centrality as measured by the CRS is a distinct phenomenon from a relationship to God and an attitude toward religion; high centrality does not necessarily mean a lack of religious doubts or crises (Zarzycka 2007).

The second stage of the adaptation process comprised of validating the CRS (Zarzycka 2011). The research was performed from 2008 to 2010. A total of 1243 people, 664 women and 563 men, aged 17 to $79(\mathrm{M}=35.22, \mathrm{SD}=16.77$ years $)$, participated in the research. The research included non-clinical samples: teachers $(n=304)$, high school graduates $(n=136)$, members of religious groups $(n=180)$, and an adult sample $(n=460)$. It also included clinical samples: patients diagnosed with asthma $(n=95)$ and psychiatric patients $(n=68)$. This stage encompassed re-analysis of the internal structure and reliability of the CRS as well as its normalization. The re-analysis was conducted by means of exploratory factor analysis, using the maximum likelihood method with a promax rotation. The analysis confirmed a five-factor structure, consistent with the assumed theoretical model. The scale items explained $73.37 \%$ of the CRS total variance. This result was similar to that obtained in the first stage of the adaptation (Zarzycka 2007). The ideology factor, similar to the first stage research results, accounted for the greatest variance $(57.04 \%)$. The variance explained by other factors were as follows: intellect $(7.47 \%)$, religious experience $(3.86 \%)$, public practice $(3.30 \%)$, and private practice $(1.67 \%$; Zarzycka 2011). There was high reliability of the total score in non-clinical and clinical samples: adults 
(0.93), teachers (0.93), high school graduates (0.95), members of religious groups (0.91), psychiatric patients (0.80), and patients diagnosed with asthma (0.96). Reliability coefficients in the subscales differed depending on the sample: from 0.80 (intellect, public practice) to 0.89 (ideology) in adults; from 0.80 (public practice) to 0.89 (intellect) in teachers; from 0.77 (private practice) to 0.89 (ideology) in high school graduates; from 0.59 (private practice) to 0.78 (experience and public practice) in religious group members; from 0.41 (private practice) to 0.68 (ideology and experience) in psychiatric patients; and from 0.82 (intellect) to 0.90 (ideology) in patients diagnosed with asthma. Therefore, it was concluded that the CRS could be considered as a reliable measure of centrality and its five dimensions in all the samples tested, excluding psychiatric patients (Zarzycka 2011). Furthermore, the private practice subscale had lower reliability in the religious group members sample. Thus, this subscale should be interpreted with caution when used in religious groups due to the small variance. The Polish version of the CRS was normalized based on the results of 1227 adults, consisting of 664 women and 563 men, aged 18 to $79(\mathrm{M}=35.22 ; \mathrm{SD}=16.77$ years $)$. Centile norms were established for the CRS total score separately for women and men (Zarzycka 2011).

\subsection{A Review of the Reserch Involving Polish CRS}

The 15-item Polish CRS has been applied to over 40 published studies, with over 18,000 total participants, to measure various psychological variables as correlates of religiosity. Particularly, the relationships between centrality of religion and four groups of variables have been reported in clinical and non-clinical samples: (1) personality traits, cognitive styles, and identity statuses; (2) social functioning; (3) religious and moral variables; and (4) mental health, quality of life, and well-being.

In the first group, with personality variables, the big five personality traits reported were academic procrastination, authoritarianism, identity statuses, superstitious thinking, and time perspective. In studies involving the big five (McCrae and Costa 1996), high agreeableness predicted high centrality and its three dimensions: ideology, private practice, and public practice. High openness predicted high interest in religious matters (intellect) but low frequency of public practice. High extraversion predicted high religious beliefs (ideology; Franczak 2009; Krok 2009b; Łowicki et al. 2018). Additionally, the features of agreeableness and altruism were the only ones that correlated positively with centrality (Śliwak et al. 2009). Informational and normative identity processing styles, as they are conceptualized in Berzonsky's theory (Berzonsky 2008), correlated positively with centrality, whereas the diffuse-avoidant style correlated negatively with centrality and all its dimensions, excluding ideology (Czyżowska and Mikołajewska 2014). Empathy and exposure to credible religious acts during childhood independently predicted centrality of religiosity (Łowicki and Zajenkowski 2019). Superstitious thinking (Krok 2007) and authoritarianism (Krok 2011) also correlated positively with centrality. Centrality dimensions also showed associations with behavioral procrastination, and these relationships were mediated by locus of control. God control was a mediator in the relationship between ideology and intellect with procrastination. Both great interest in religious matters and strong religious beliefs increased God control, which in turn decreased behavioral procrastination. Internal control mediated the effect of public practice and religious experience with procrastination. Both religious experience and public practice decreased internal control, which in turn increased the tendency to procrastinate. Furthermore, passive style of prayer was a mediator in the relationship between centrality and procrastination. Centrality increased the tendency to procrastinate through its effect on passive prayer (Zarzycka et al. 2019). There were also correlations between centrality and time perspective. Centrality correlated positively with past-positive and future-positive orientations. Religious experience was positively associated with past-positive, present-hedonism, present-fatalism, and future-positive, and negatively associated with past-negative (Eowicki et al. 2018).

In the second group, including social variables, centrality presented relationships with parental attitudes, social orientations, social competences, social desirability, political attitudes, and civic involvement. The CRS was applied to measure associations between retrospectively assessed parenting styles and religiosity (Żurek 2015). The results showed that men's religiosity was more strongly 
influenced by the parenting styles experienced during childhood compared to women's religiosity. Among men, a father's democratic parenting styles correlated positively with ideology, private and public practice, and religious experience. A father's liberal-loving parenting style correlated positively with religious experience and public practice. There was also a negative relationship between a father's liberal-unloving style with private practice, as well as positive correlation between a mother's democratic style with intellect and private practice. Among women, neither mother's nor father's parenting styles correlated with centrality (Krupa 2015; Żurek 2015). Of social orientations, collectivism - both vertical and horizontal—was confirmed as a positive correlate of centrality and all its dimensions (Tychmanowicz et al. 2018; Zarzycka et al. 2016). Individualism was confirmed as a negative correlate of centrality (Zarzycka et al. 2016). Furthermore, centrality positively predicted supportive, overprotective, cooperative, and submissive styles of social functioning and negatively predicted authoritative leadership and rebelliously suspicious and competitively narcissistic styles (Händel 2017). Relationships between centrality and social competences were confirmed. Ideology correlated positively with competence in social exposure situation behavior and assertiveness as competence. Religious experience correlated negatively with social exposure situation behavior. Public practice correlated positively with assertive behavior (Rydz and Zarzycka 2008). There were no significant correlations between centrality and social desirability (Zarzycka and Rydz 2011). Centrality and all its dimensions correlated positively with civic involvement among middle-aged women. Similar correlations were found among the younger and older female groups; however, they referred to civil involvement and private and public practice (Turska-Kawa 2018). With regards to political attitudes, centrality — and all its dimensions, excluding intellect-strengthened support for right-wing political parties in academic youth (Krok and Żak 2007) and were associated with a low openness to an international career (Goździewicz-Rostankowska et al. 2018).

In the third group, including religious and moral variables, there were relationships between centrality and religious attitude, structure of religiosity, post-critical beliefs, religious identity, emotions toward God, attachment to God, religious crisis, religious struggles, deconversion, readiness to engage in interreligious dialogue, and moral development. Centrality, and its dimensions, correlated positively with the intensity of a positive religious attitude (Szymołon and Bartczuk 2011). Four dimensions of the structure of the traditionally defined religiosity—religious awareness, religious practices, morality, and forms of profession of faith - were positively related to centrality (Tatala et al. 2017). Relativism and external critique, which are the measures of the religious attitudes in a secularized context, correlated negatively with centrality (Bartczuk et al. 2011). These results are supported by Rydz and Wieradzka-Pilarczyk (2018) research, which showed that people with internalized religious identity status had higher scores in centrality, whereas people seeking religious identity status had lower scores in centrality. The research on emotions and attachment to God further broadened these findings. Positive emotions toward God, gratitude/adoration, prayers of request (Bartczuk and Zarzycka 2019; Zarzycka and Bartczuk 2011), and secure attachment to God (Matys and Bartczuk 2011) correlated positively with centrality, whereas anxious attachment to God was negatively correlated. Centrality moderated the relation between a personal perception of God and anger toward God. Those with low centrality and a personal God concept felt stronger anger toward God. Whereas high centrality weakened anger toward God in individuals with a personal God image (Zarzycka 2016). Centrality of religion was also a positive predictor of the readiness to engage in interreligious dialogue, in particular readiness to communicate on religious topics and seek mutual understanding. On the other hand, it was a negative predictor of the personal barriers to the symmetry of dialogue. Intellect had the strongest positive relationship with readiness to engage in interreligious dialogue, which is not surprising because interreligious dialogue implies interest in religion (Rydz et al. 2019). Inverse—mostly negative—correlations were observed between centrality and measures of religious crises and abandonment of faith. Religious crisis was negatively related to centrality (Buksik 2009), as were religious struggles: divine, ultimate meaning (Zarzycka et al. 2018), and interpersonal struggle among women (Zarzycka 2017). Demonic and moral struggle correlated positively with centrality, a finding that is not surprising given that high religious 
involvement is accompanied by a concern about living up to the moral standards of religion and with a stronger belief in a supernatural reality, including a stronger belief in the existence of evil spirits (Zarzycka 2017; Zarzycka et al. 2018). The relationship between centrality and moral struggle was moderated by a change in religious affiliation. The more central the position of the religious meaning system in personality is, the stronger the moral struggle in people who change their religious affiliation (Zarzycka 2017).

Finally, centrality was a negative predictor of deconversion in youth (Nowosielski and Bartczuk 2017). Centrality was a negative predictor of hedonistic values (Krok 2010) and a positive predictor of the preference of moral and sacred values and meaning in life (Krok 2016b). Centrality-as well as its five dimensions-was associated with the second (pre-conventional) and fourth (conventional level) stages of moral development in Kohlberg's stages of moral development (Czyżowska and Mikołajewska 2012).

In the fourth group, including mental health and well-being variables, positive and negative mood, sense of coherence, professional burnout, anxiety, and attitudes toward illness were reported as correlates of centrality. The observed correlation patterns suggest that centrality correlated positively with the indicators of good health and well-being. In non-clinical samples, centrality correlated positively with sense of coherence (Czyżowska and Gurba 2016). However, there were moderating effects of gender and age: a positive relationship between centrality and sense of coherence was significant in middle-aged men and younger and older females (Zarzycka and Rydz 2014). There were negative correlations among centrality and its three dimensions (intellect, private practice, and religious experience) and somatic symptoms as measured by the General Health Questionnaire (Goldberg and Williams 2001). Prayer correlated negatively with anxiety and insomnia (Krok 2014). Centrality affects how people cope with difficult situations: private and public practice supports avoidant, positive re-evaluation, and confrontation strategies (Franczak 2012). Centrality was a protective factor against professional burnout in teachers (Krasiczyńska 2010). There were neither positive nor negative relationships between centrality and mood (Krok 2009a). In clinical samples, intellect and public practice predicted the quality of life in people with cancer, with death anxiety mediating this relationship (Rybarski 2019). All centrality dimensions were positively associated with assessing cognitive representations of illness perception of a disease (value, benefit, and challenge), whereas ideology correlated negatively with assessing illness as harm among asthma patients (Bartczuk 2011). The relationships between centrality and quality of life were also examined in a family setting (among parents and their adolescent children). In the parent sample, centrality of religiosity was positively related to subjective quality of life and its four (out of seven) dimensions: productivity, intimacy, safety, and emotional well-being. Three dimensions of centrality, consisting of ideology, experience, and private practice, positively correlated with quality of life. There were also positive correlations between centrality and satisfaction with life. Similarly, in the adolescent sample, centrality positively correlated with quality of life and its four dimensions: productivity, intimacy, safety, and emotional well-being. In contrast to the parent group, there were no associations between measures of religiosity and material well-being (Krok 2016a).

The CRS scale has gained a lot of interest among Polish researchers due to the fact that religiousness in Poland still plays a significant role in the lives of individuals. The Public Opinion Research Center (CBOS) in Poland reported in 2018 that declarations regarding faith in God are almost universal and change only slightly. Research shows that since the end of the 1990 s, over $90 \%$ of those surveyed $(92-97 \%)$ have consistently declared themselves as believers, including roughly one in ten that evaluate their faith as profound. Research to date has confirmed that CRS is a reliable and validate method for measuring the centrality of religiosity in the Polish cultural context.

\subsection{The Purpose of the Study}

Huber comprehensively and theoretically justified the transformation of continuous measurement of the centrality of religiosity into categorical and discontinuous measurement of distinct positions of the religious construct-system in personality (Huber 2003, 2007, 2008b). Such categorization “enables 
an empirical research strategy concerning the relationship between the aspects of the centrality and the specific content of the religious construct-system" (Huber 2007, p. 221). As presented in the introduction above, the distinction of the categories has enabled testing of hypotheses regarding the differentiation of religious content (differentiation thesis), as well as the relative importance of religious and non-religious psychosocial constructs (thesis of relevance). For the categorization of the groups, Huber proposed "intuitive" thresholds (1.0 to 2.0, not-religious; 2.1 to 3.9, religious; 4.0 to 5.0, highly-religious) that can be understood in an intuitive manner derived from the wording of the five levels of the frequency and intensity response scales related to the presence of religious constructs in the personal religious construct system. The current study attempts to determine empirically the thresholds for the categories of centrality and to deepen the understanding of what these categories are.

We were prompted to undertake such research by discovering in some studies that the relationship between centrality and other religious variables can be better explained by assuming that they are curvilinear rather than linear. Bartczuk (2011), in his study of people with asthma ( $n=98)$, distinguished groups of people with central and peripheral religiosity based on the curvilinear relationship of CRS with the measure of the importance of striving for the growth of personal religious faith. This categorization was a moderator of centrality's relationship with the appraisal of one's own illness and the assessment of the realization of personal strivings in the illness. Zarzycka (2017), using a non-clinical adult sample $(n=1265)$, showed a curvilinear relationship between centrality and moral religious struggles that remained significant even after controlling for religious comfort. In a study of palliative cancer patients $(n=130)$, Rybarski (2019) showed curvilinear relationships of centrality with global religious strain and with all types of struggles: fear/guilt, divine struggle, and interpersonal struggle. These curvilinear relationships were reflected in indirect effects of centrality on death and dying distress, and on the quality of life of cancer patients. These results suggest that groups with distinct religious status vary in the differentiation of religious content, as Huber assumed, and the categories of centrality moderate the dependence of religious contents on centrality. With this assumption and by analyzing the shape of the relationship between centrality and other religious contents, we can determine the threshold values of CRS results at which these relationships change. To this end, we analyzed the relationship between CRS and some content scales of the religious structure test (see Figure 1).

\section{Results}

The aim of the study was to examine whether the relationships between centrality and other religious variables are curvilinear. This phenomenon would indicate a differentiation in the function of centrality of religiosity. To this end, the relationships between CRS and the emotions toward God scale $(\mathrm{EtG})$ and content of prayer scale (CoP) subscales wer analyzed. Descriptive statistics and correlations between all the variables included in the study are presented in Table 2.

Table 2. Means, standard deviations, and correlations with centrality with confidence intervals of variables in the study $(n=2331)$.

\begin{tabular}{lcccc}
\hline \multicolumn{1}{c}{ Variable } & $\boldsymbol{M}$ & SD & $\boldsymbol{r}$ & $\mathbf{9 5 \%} \boldsymbol{C I}$ \\
\hline 1. Centrality & 3.71 & 0.74 & & \\
2. Positive EtG & 3.76 & 0.75 & $0.78^{* *}$ & {$[0.76,0.79]$} \\
3. Anger EtG & 2.04 & 0.86 & $-0.17^{* *}$ & {$[-0.21,-0.13]$} \\
4. Fear EtG & 2.58 & 0.97 & $0.11^{* *}$ & {$[0.07,0.15]$} \\
5. Guilt EtG & 2.85 & 0.89 & $0.25^{* *}$ & {$[0.21,0.29]$} \\
6. Adoration P & 3.68 & 0.87 & $0.76^{* *}$ & {$[0.74,0.78]$} \\
7. Fear P & 1.56 & 0.68 & $-0.15^{* *}$ & {$[-0.19,-0.11]$} \\
8. Repine P & 2.17 & 0.79 & $0.16^{* *}$ & {$[0.12,0.20]$} \\
9. Self-Directive SRP & 3.24 & 0.94 & $0.54^{* *}$ & {$[0.51,0.56]$} \\
10. Colaborative SRP & 3.94 & 0.80 & $0.62^{* *}$ & {$[0.59,0.64]$} \\
11. Passive SRP & 2.98 & 1.00 & $0.40^{* *}$ & {$[0.36,0.43]$} \\
\hline
\end{tabular}

Notes: $M, S D, r$, and $95 \% C I$ are used to represent mean, standard deviation, Pearson coefficient of correlation with centrality, and it's $95 \%$ confidence interval boundaries, respectively. The confidence interval is a plausible range of population correlations that could have caused the sample correlation (Cumming 2014). In labeling variables, EtG is used for emotion(s) toward God, P for prayer, and SRP for style of request prayer. ${ }^{* *}$ indicates $p<0.01$. 
As shown in Table 2, all correlations were statistically significant. However, the study included religious variables with different degrees of linear relationships with centrality, ranging from the fear of God, which was minimally correlated with centrality, to positive emotions toward God and prayer of adoration, which were highly correlated with centrality. We also included two religious variables that were negatively related to centrality: the emotion of anger toward God and the repine prayer. This selection allowed us to comprehensively test a research problem. The relationships between centrality and the tested religious variables are illustrated using splines (Figure 1).

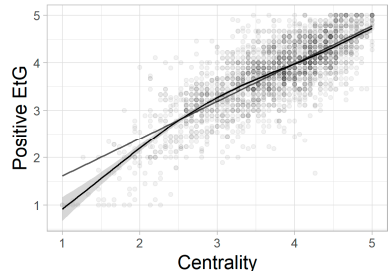

(a)

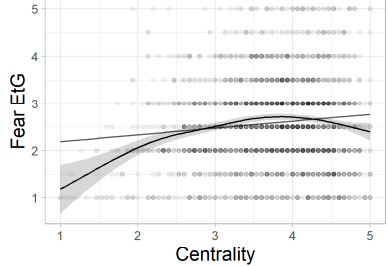

(c)

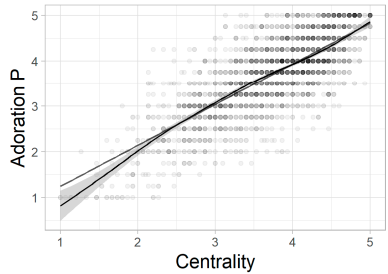

(e)

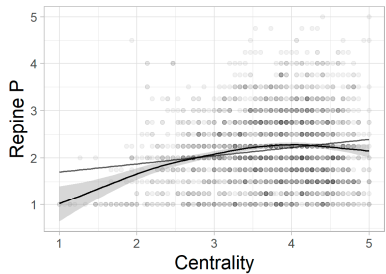

(g)

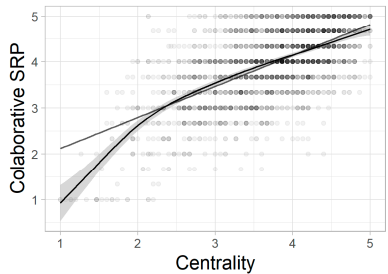

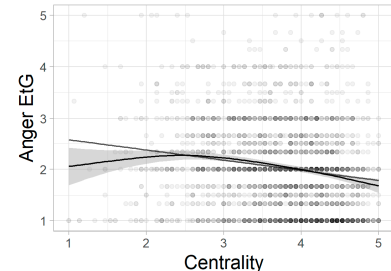

(b)

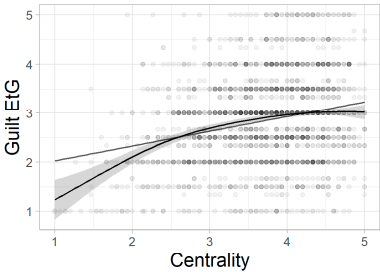

(d)

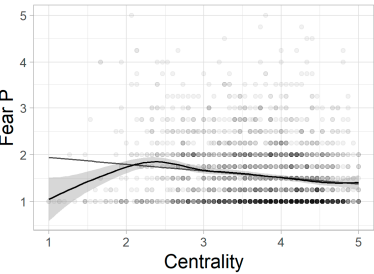

(f)

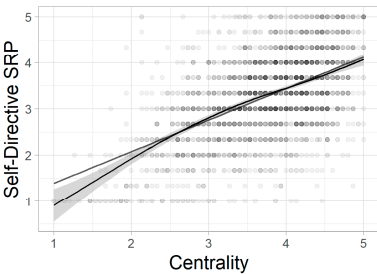

(h)

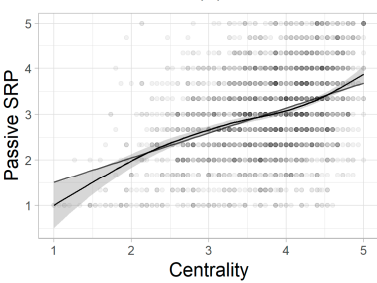

(j)

Figure 1. Relationships between centrality of religiosity scale (CRS) and religious structure test (RST) subscales included in the study $(n=2331)$. Gray lines describe linear models, black lines indicate semiparametric models using splines, and the gray area is $95 \%$ confidence interval (CI) for the splines. The panels show the following regressions on CRS: (a) positive emotions toward God; (b) anger toward God; (c) fear toward God; (d) guilt toward God; (e) adoration prayer; (f) fear prayer; (g) repine prayer; (h) self-directive style of request prayer; (i) collaborative style of request prayer; and (j) passive style of request prayer. 
The analysis of Figure 1 indicated: (1) a possible curvilinear relationship in most cases and (2) problems with heteroscedasticity. The semiparametric regression line for each of the explained variables deviated from the linear regression line, regardless of whether it applied to cases where the linear relationship was positive or negative, and in the case of positive, whether it was strong or weak. The second phenomenon had two potential sources. The first was the theoretically assumed differentiation of religious contents in groups with different centrality, and the second was the poor representation of people with low results.

To test for a possible breakpoint in the association between centrality of religiosity and religious contents, we applied segmented regression analysis (Muggeo 2003, 2017). This method is preferred over semiparametric regression because it gives simple and interpretable parameters, slopes, and particularly, changepoints. The estimated breakpoints are presented in Table 3. According to a score test (see Table 3), all but one changepoint (for passive style of request prayer) were statistically significant.

Table 3. The results of segmented regressions and changepoints tests.

\begin{tabular}{|c|c|c|c|c|c|c|c|c|c|c|}
\hline Variables & $\psi$ & $\psi 95 \% C I$ & $S$ & $D$ & $B_{1}$ & $B_{1} 95 \% C I$ & $B_{2}$ & $B_{2} 95 \% C I$ & Int & $R^{2}$ \\
\hline Positive EtG & 2.73 & {$[2.549,2.917]$} & $-7.57^{* * *}$ & 4.56 & 1.27 & {$[1.112,1.422]$} & 0.70 & {$[0.668,0.738]$} & -0.37 & 0.62 \\
\hline Anger EtG & 2.47 & {$[2.092,2.842]$} & $-3.73^{* * *}$ & 4.56 & 0.39 & {$[-0.025,0.807]$} & -0.26 & {$[-0.315,-0.199]$} & 1.41 & 0.04 \\
\hline Fear EtG & 3.63 & {$[3.423,3.836]$} & $-7.34^{* * *}$ & 1.89 & 0.44 & {$[0.327,0.562]$} & -0.22 & {$[-0.366,-0.077]$} & 1.16 & 0.03 \\
\hline Guilt EtG & 2.48 & {$[2.223,2.738]$} & $-5.87^{* * *}$ & $4.11^{\dagger}$ & 1.09 & {$[0.700,1.479]$} & 0.22 & {$[0.160,0.279]$} & -0.10 & 0.07 \\
\hline Adoration P & 2.75 & {$[2.406,3.099]$} & $-3.74^{* * *}$ & 4.56 & 1.17 & {$[0.998,1.340]$} & 0.84 & {$[0.799,0.888]$} & -0.33 & 0.58 \\
\hline Fear P & 2.13 & {$[1.892,2.374]$} & $-2.72^{* *}$ & 4.56 & 0.77 & {$[0.280,1.268]$} & -0.18 & {$[-0.225,-0.140]$} & 0.20 & 0.03 \\
\hline Repine P & 3.47 & {$[3.228,3.712]$} & $-6.57^{* * *}$ & 2.33 & 0.43 & {$[0.320,0.537]$} & -0.05 & {$[-0.152,0.053]$} & 0.79 & 0.04 \\
\hline Self-Directive SRP & 2.81 & {$[2.418,3.199]$} & $-3.77^{* * *}$ & 4.56 & 1.03 & {$[0.790,1.269]$} & 0.61 & {$[0.543,0.668]$} & -0.17 & 0.29 \\
\hline Colaborative SRP & 2.12 & {$[1.934,2.299]$} & $-7.04^{* * *}$ & 3.22 & 2.06 & {$[1.524,2.587]$} & 0.61 & {$[0.574,0.651]$} & -1.37 & 0.40 \\
\hline Passive SRP a & 4.81 & {$[4.632,4.984]$} & -0.50 & & $0.54 \mathrm{a}$ & {$[0.765,0.817] \mathrm{a}$} & & & $0.96 \mathrm{a}$ & $0.16 \mathrm{a}$ \\
\hline
\end{tabular}

Notes: $\psi$ and $\psi 95 \% C I R_{2}$ are used to represent changepoint estimate and the associated $95 \%$ confidence interval boundaries; $S$ and $D$ to represent the score test for the first changepoint statistic and Davis test for the second changepoint, respectively; $B_{1}, B_{1} 95 \% C I, B_{2}, B_{2} 95 \% C I$, Int, and $R^{2}$ represent the first segment slope and the associated $95 \%$ confidence interval boundaries, second segment slope, and $95 \%$ confidence interval boundaries, intercept, and coefficient of determination, respectively. In labeling variables, EtG is used for emotion(s) toward God, P for prayer, and SRP for style of request prayer. a The passive SRP are parameters of the linear regression model. ${ }^{\dagger}$ indicates $p<0.1{ }^{* *}$ indicates $p<0.01^{* * *}$ indicates $p<0.01$.

Table 3 also contains parameters of the obtained segmented regression models, and an illustration of these relationships is shown in Figure 2. The range of variances of religious contents explained by centrality was variable and ranged from 3\% (for fear towards God and prayer of fear) to 62\% (for positive emotions towards God). All models, except for anger towards God, contained significant positive predictions of contents in the first segment of the model. The second segments of the models were also mostly significant; the exception was the second slope for the repine prayer, which turned out to be insignificant, and the model for passive style of request prayer, which was not segmented because no significant changepoint was found. Among the significant second segments, three were negative: anger toward God, fear toward God, and fear prayer, while the others were positive. 


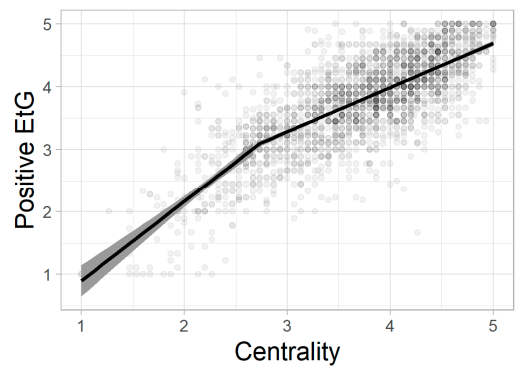

(a)

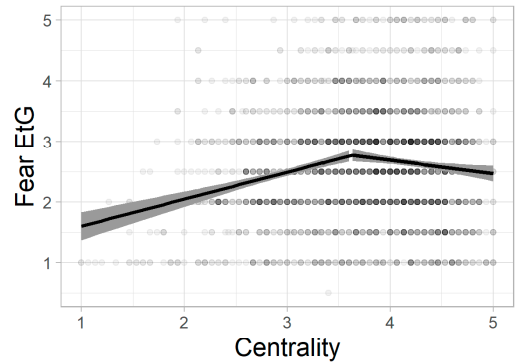

(c)

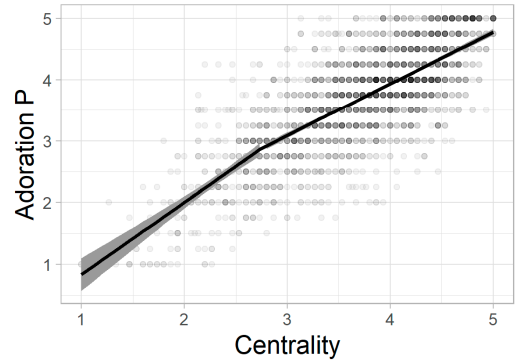

(e)

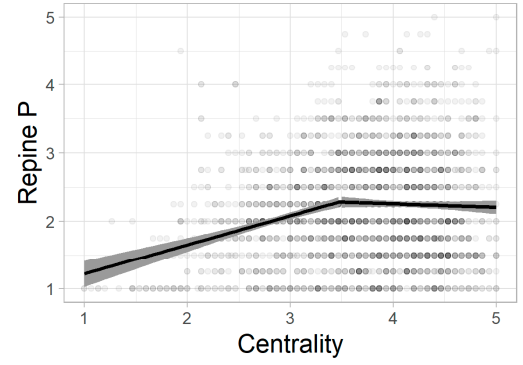

(g)

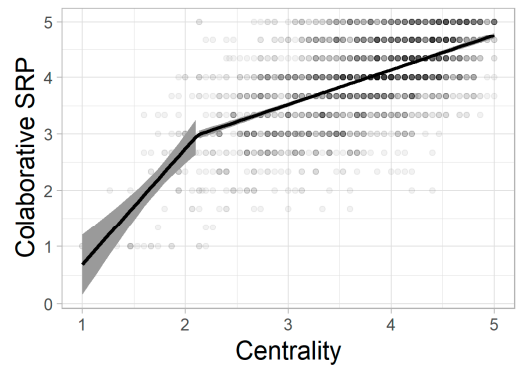

(i)

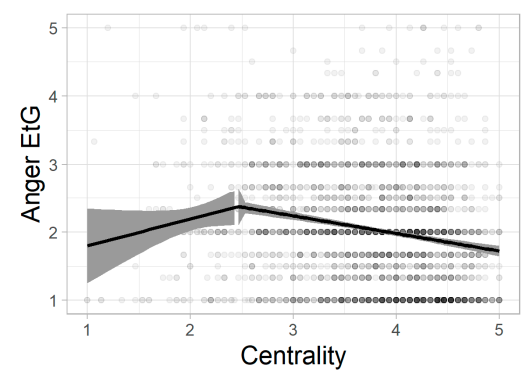

(b)

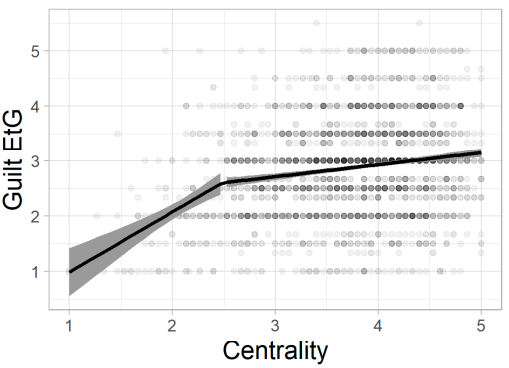

(d)

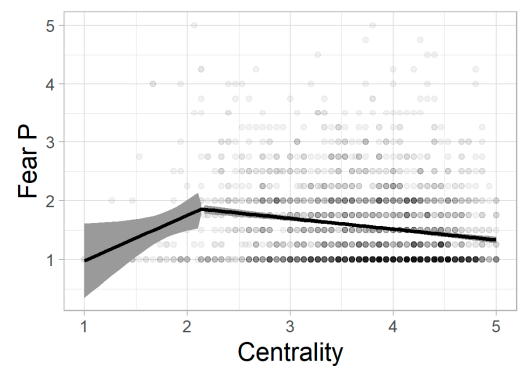

(f)

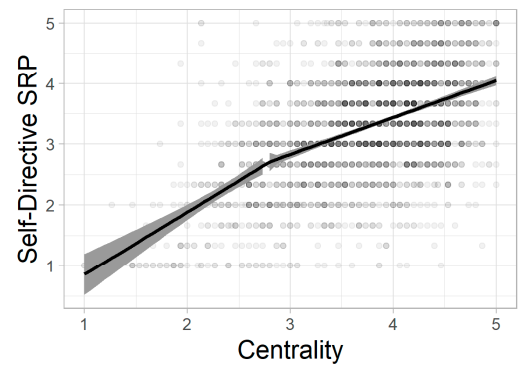

(h)

Figure 2. Segmented regression lines for relations between scores of CRS and scores of SRT subscales included in the study $(n=2331)$. Black lines are segmented regression lines, gray area is their $95 \%$ confidence interval (CI). On panels are regressions on centrality, respectively: (a) positive emotions toward God; (b) anger toward God; (c) fear toward God; (d) guilt toward God; (e) adoration prayer; (f) fear prayer; (g) repine prayer; and (h) self-directive style. 
In search of the proper model of the relationship between centrality and religious contents, the potential presence of a second changepoint was also tested for each model using the more conservative Davies test. This method presents more power than the score test if there are two or more breakpoints (Muggeo 2016). The Davies test did not show the presence of the second changepoint, although it is worth noting that the Davies test and score test were inconsistent in the case of four relationships: fear toward God, guilt toward God, repine prayer, and collaborative style of request prayer.

The attempt to determine CRS score ranges that define the different statuses of the system of religious constructs in personality was therefore based on the results of one changepoint for each content. The estimates of these changepoints are presented in Figure 3.

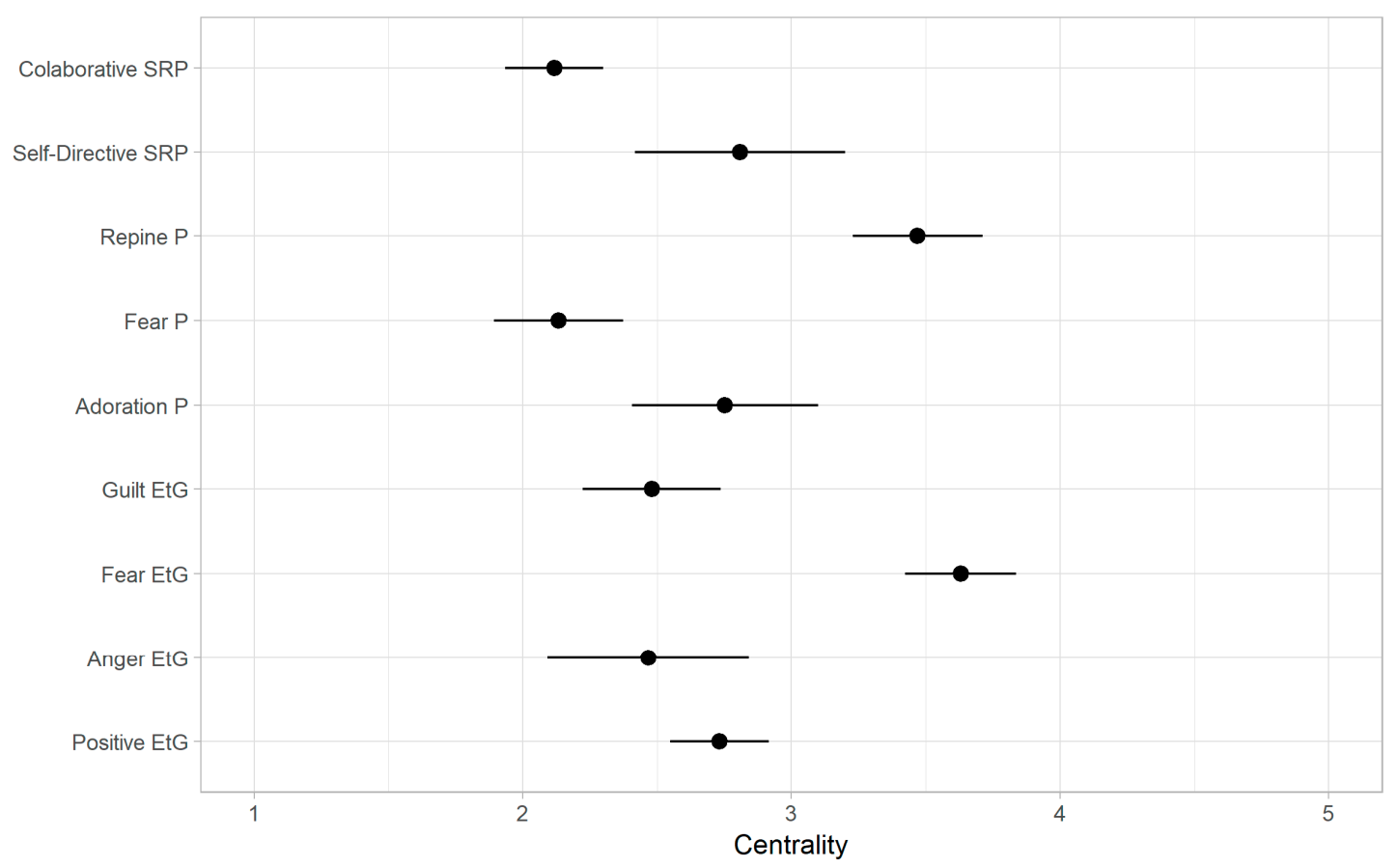

Figure 3. Estimates of changepoints in segmented regressions and their $95 \%$ confidence intervals.

The obtained confidence intervals for individual changepoints indicated that they appeared in the CRS range from 1.89 to 3.84. There were also significant differences among changepoints because their confidence intervals did not always overlap. The lowest ranked changepoints appeared in collaborative style and fear prayer, while the highest ranked ones were in the repine prayer and fear toward God.

\section{Discussion}

The foregoing analyses allowed us to draw some conclusions regarding the mechanisms through which centrality connects to other religious variables, particularly emotions toward God, prayer types, and styles of request prayer. Overall, there was a curvilinear relationship between centrality of religiosity and emotions toward God, prayer types, and styles of request prayer (excluding passive request prayer). More specifically, we determined the changepoints, i.e., the points at which the relationship between the centrality of religiosity and the measured variables changed. These data allowed us to empirically determine the three CRS score ranges: the first one in which changepoints did not appear, the second one in which changepoints appeared, and the third one in which changepoints did not appear. These intervals provided empirical confirmation of Huber's thesis (Huber 2003) that there is a different way of operating low, medium, and high scores in centrality, namely marginal, subordinated, and central religiosity.

In the low results range, the increase in centrality conditions corresponded with the appearance of religious contents. With regards to high results, the specification of these religious contents depended 
on centrality: positive religious contents were strengthened by centrality, while negative religious contents (excluding guilt toward God) were weakened. Our results indicated that the range in which the changepoints occur (1.89 to 3.84) can be located in the subordinated religiosity, which Huber indicated between 2.0 and 4.0. These intervals are not completely the same, but the former was slightly shifted toward low results.

We also attempted to model three intervals in the form of regression with three segments, but this endeavor failed for each of the analyzed religious contents.

The theoretical conclusion drawn from these results is that subordinated religiosity can be understood as a "transition zone" between marginal and central religiosity. If so, it combines the features of marginal and autonomous religiosity, rather than has its own characteristics. One explanation for this finding is that it is probably (according to Huber's theory) an area in which relationships between centrality and other variables are moderated by various factors, in particular personal constructs with a higher salience in personality compared to religion. For example, we can expect that in the range of subordinated religiosity, centrality will be associated with a cruel image of God more strongly in people with high authoritarianism than in those with low authoritarianism. Another explanation that arises from our results is that the transition from the marginal religiosity to the central religiosity effects occurs at different levels of centrality for different religious contents. For example, the results for the fear prayer and emotion of fear towards God-which at first glance refer to the same religious (or theological) content, are representative here. The confidence intervals for changepoints obtained in the analyses for these two variables differed significantly (see Figure 3). A change in the relationship between prayer expressing fear and centrality occurred below the middle of the CRS range, while a change for the feeling of fear was above the middle of the CRS range. These results suggest that prayer of fear begins decreasing at relatively low centrality, while the tendency to experience fear of God begins to decrease at relatively high centrality results. Thus, subordinated religiosity can be a type in which religiosity works as central for some religious content, but not to others.

The dependence of affective positive religious content (positive emotions toward God, adoration prayer, and collaborative and self-directive prayer request) on centrality presents the following pattern: the greatest increase of this religious content is in the case of marginal religiosity, then the effect of centrality on these variables is still positive but weaker. The first effect is attributed to the increase in the frequency and importance of the religious construct system itself, followed by the appearance of more and more religious content (no matter the type). In central religiosity, this increase is paradoxically weaker. Current research does not allow for a thorough understanding of this relationship, but it is possible that basic positive content is already acquired, their development requires more effort, or the proper (central) function of centrality is subtler, expressed in different qualities than in the number or frequency of religious content occurrence. This image is analogous to spiritual transformation. In a situation of religious conversion, people experience a stronger increase in positive emotions toward God and commitment to the adoration prayer, while later, this increase is smaller. The opposite phenomenon may also occur in a similar way, i.e., the process of departing from religion may initially be gradual, and then increase at a faster pace (Paloutzian et al. 2013).

Religious contents with an affectively negative charge (emotions: fear and anger toward God; prayer: fear and repine) depended on centrality in a different way: their increase was the highest within the low centrality results (excluding the increase in anger toward God, which was insignificant). However, by a further increase in centrality, the intensity of fear and anger toward God and fear prayer decreased, while the relationship between repine prayer and centrality approached insignificance. Therefore, in the low results, the mechanism described above (characteristic of marginal religiosity) is applicable. On the other hand, central religiosity can weaken negative religious content, which is often associated with stress and life events. This interpretation is confirmed by studies on the relationship between centrality and religious struggles, namely divine and negative social interactions surrounding religion (Zarzycka 2017). The only exception was guilt toward God, which showed a relationship similar to positive rather than negative contents. However, guilt often shows positive relationships 
with religiousness and of moral conflicts (Luyten et al. 1998). This phenomenon is not about linking religiosity with guilt, as it was presented by Freud (Freud 2009) and psychoanalysis. Rather, it is about guilt understood as a sense of responsibility for a religious relationship.

In conclusion, with low centrality, both positive and negative emotions toward God increased, while with the increase in centrality, there was a kind of polarization of emotions. High centrality was accompanied by positive, rather than negative, emotional attitudes toward God and prayer of adoration, rather than fear or repine. The increase in centrality performs a regulatory function by weakening negative emotions towards God and strengthening positive emotions. It is likely that this curvilinear effect will also be used in studies on the relationship between centrality and other psychological variables that are not necessarily religious. It will perhaps shed light on results in which the centrality of religiosity is a moderator of the relationship between religious variables such as prayer and other health-related variables (e.g., Dezutter et al. 2011). At this stage, the scope of our data do not allow us to perform detailed analyses. However, the results of previous studies indicate the accuracy of such a prediction (Bartczuk 2011; Rybarski 2019). For example, Rybarski (2019) showed that in cancer patients, the indirect effect of centrality on death anxiety mediated by religious struggles was positive at low centrality and negative at high centrality. This means that when centrality is low (marginal), it increases death anxiety by increasing religious struggles. However, when centrality is high (central), it reduces death anxiety by reducing religious struggles.

With regards to shortcomings of the study, it should be emphasized that we studied a limited number of religious contents. The study lacked low CRS results as there were samples that lacked the lowest results, a deficit that affected the ability to estimate the number of changepoints and the regression line of the first segment (which usually has a wider confidence interval in our results). We also used two versions of the CoP scale that differed slightly in item wording. Therefore, the results obtained in our study should be interpreted carefully and treated as preliminary.

\section{Materials and Methods}

\subsection{Participants and Procedure}

Eleven samples of adults participated in the study. The total sample comprised 2331 persons (60.8\% women), aged from 16 to $79(\mathrm{M}=32.7, \mathrm{SD}=14.25$ years). Most of the respondents $(n=1813$, $97.9 \%$ ) declared themselves to be Roman-Catholic. The number, age, and gender of the samples are shown in Table 4. The student samples (4 and 5) consisted of psychology students attending various universities in Lublin. Students received credit points in return. Adult respondents from samples 1, $2,3,6$, and 7 were recruited by students, who asked their acquaintances to fill in the questionnaire. Subjects from samples 8,10 , and 11 were recruited by means of the "snowball" sampling method. Purposive sampling was used in order to recruit sample 9.

Table 4. The characteristic of the participants.

\begin{tabular}{lccccccc}
\hline \multirow{2}{*}{ Sample } & $\mathbf{n}$ & \multicolumn{2}{c}{ Sex } & \multicolumn{3}{c}{ Age } \\
\cline { 4 - 8 } & & & \% Women & M & SD & min & max \\
\hline Sample 1 & Adults & 113 & 0.9 & 41.71 & 16.283 & 18 & 79 \\
Sample 2 & Adults & 165 & 49.1 & 42.02 & 17.256 & 16 & 78 \\
Sample 3 & Adults & 197 & 51.3 & 25.55 & 9.624 & 19 & 60 \\
Sample 4 & Students & 194 & 72.2 & 27.54 & 9.689 & 17 & 65 \\
Sample 5 & Students & 141 & 90.1 & 20.52 & 2.102 & 18 & 32 \\
Sample 6 & Adults & 168 & 0.0 & 20.63 & 2.005 & 18 & 35 \\
Sample 7 & Adults & 209 & 51.7 & 38.95 & 8.645 & 26 & 59 \\
Sample 8 & Adults & 326 & 98.2 & 21.17 & 2.331 & 18 & 37 \\
Sample 9 & Teachers & 293 & 91.5 & 34.82 & 13.323 & 18 & 75 \\
Sample 10 & Adults & 140 & 42.9 & 42.40 & 16.351 & 18 & 74 \\
Sample 11 & Adults & 385 & 54.0 & 30.12 & 11.399 & 16 & 66 \\
\hline & Total & 2331 & 60.8 & 32.66 & 14.246 & 16 & 79 \\
\hline
\end{tabular}




\subsection{Measures}

Huber $(2006,2008$ a) developed the RST, a multidimensional method for measuring the centrality and content of religiosity. The measurement of centrality was performed using the CRS. The content of religiosity can be assessed using content scales, which do not constitute a single test, but rather a collection of measures of various elements of the religious meaning system, such as emotions toward God, religious coping styles, or religious attitudes. We applied two methods to measure the content of religiosity: the emotions toward God scale $(\mathrm{EtG})$ and the content of prayer scale (CoP).

\subsubsection{CRS}

The CRS is a measure of the importance of religion in personality. The CRS consists of 15 items divided into five subscales: intellect, ideology, private practice, religious experience, and public practice. It has been developed by Huber (Huber and Huber 2012) and adapted into Polish by Zarzycka $(2007,2011)$. Psychometric properties of the Polish version of the CRS are given above in the introduction section.

\subsubsection{EtG Scale}

The EtG consists of 16 items that stand for the emotions experienced by a person in their relationship toward God. The EtG scale comprises four subscales: positive emotions, anger, fear, and guilt. Using a 5-point scale (1 (never), 2 (rarely), 3 (sometimes), 4 (often), and 5 (very often)) the respondents mark the relative frequency of the situations in which they experience each emotion. The EtG was developed by Huber and Richard (2010) and adapted into Polish by Zarzycka and Bartczuk (2011). Psychometric properties of the Polish version of the EtG were satisfactory. High reliability coefficients (Cronbach's $\alpha$ ) were obtained in different samples: from 0.90 to 0.97 for positive emotions and from 0.74 to 0.90 for negative emotions. In the negative emotion subscales, $\alpha$ was also high for anger (from 0.74 to 0.87 ), while for anxiety, it was from 0.69 to 0.89 . The external and internal validity of the EtG has been confirmed (Zarzycka and Bartczuk 2011).

\subsubsection{CoP Scale}

The CoP consists of 20 items enumerating the experiences and invocations that people offer to God during their prayer, such as gratitude, asking for help, or complaining about God. The instruction contains the following question: How often do you experience the following in your prayer? The response options are as follows: 1 (never), 2 (rarely), 3 (sometimes), 4 (often), and 5 (very often). Positive aspects of prayer were collected into the gratitude/adoration subscale, while negative aspects of prayer were collected into the fear and repine subscales. The CoP also contains three subscales that measure styles of request: self-directive, cooperative, and passive. The CoP was developed by Huber (2006, 2008a) and adapted into Polish by Bartczuk and Zarzycka (2019). In the current study, two Polish CoP versions were used. In samples 1-7, the translation of the original CoP (CoP-PL) was used, and in samples 8-11, a revised version of the CoP was applied (CoP-PL-R; see Bartczuk and Zarzycka 2019). The results from both versions were obtained using the same range by averaging item scores. The reliability of the CoP-PL was examined using Cronbach's $\alpha$. All CoP subscales had high reliability in all samples: adoration, repine, and passive showed very high reliability $(>0.80)$; the reliabilities of remaining subscales were greater than 0.70 .

\subsection{Statistical Analysis}

The modeling of relationships between CRS scores and other variables was performed using segmented regression. These regression models represent the relationships between the criterion variable and one or more explanatory variables by two or more straight lines connected at unknown values, usually referred to as change-points (Muggeo 2008). In analyses of data from CRS studies, data have typically been modeled using either linear models or analysis of variance (ANOVA). However, 
segmented modeling may provide a framework that leads to a better fit when regression lines show two or more clear-cut phases.

Author Contributions: B.Z. wrote Introduction section; R.P.B. analyzed the data and wrote Results section. B.Z. and R.P.B. conducted the research, collected the data, and wrote the Materials and Methods and Discussion sections. R.R. collected the Polish literature using the CRS, prepared the annotated bibliography, and contributed to the Discussion section. All authors have read and agreed to the published version of the manuscript.

Funding: This research received no external funding.

Conflicts of Interest: The authors declare no conflict of interest.

\section{References}

Bartczuk, Rafał P. 2011. Religijność a ocena własnej choroby. Badania osób chorych na astmę oskrzelową [Religiosity and the Appraisal of Illness. Study of People with Asthma]. Ph.D. thesis, The John Paul II Catholic University of Lublin, Lublin, Poland.

Bartczuk, Rafał P., and Beata Zarzycka. 2019. Theory-Driven Measurement of the Content of Prayer: Polish Revision of S. Huber's Content of Prayer Scale. Mental Health, Religion E Culture. [CrossRef]

Bartczuk, Rafał P., Michał Wiechetek, and Beata Zarzycka. 2011. Skala Przekonań Postkrytycznych D. Hutsebauta [Post-Critical Beliefs Scale by D. Hutsebaut]. In Psychologiczny pomiar religijności [Psychological Measurement of Religiosity]. Edited by Marek Jarosz. Lublin: Towarzystwo Naukowe KUL, pp. 201-29.

Bartczuk, Rafał P., Beata Zarzycka, and Michał Wiechetek. 2013. Struktura wewnętrzna polskiej adaptacji Skali Przekonań Postkrytycznych [The Internal Structure of the Polish Adaptation of the Post-Critical Beliefs Scale]. Roczniki Psychologiczne 16: 539-61.

Berzonsky, Michael D. 2008. Identity Processing Style and Defensive Mechanisms. Polish Psychological Bulletin 39: 111-17. [CrossRef]

Buksik, Dariusz. 2009. Religijność a kryzys w wartościowaniu [Religiosity and the Crisis in Valuation]. In Osobowość i religia [Personality and Religion]. Edited by Henryk Gasiul and Emilia Wrocławska-Warchala. Warszawa: Wydawnictwo UKSW, pp. 437-57.

Cumming, Geoff. 2014. The New Statistics: Why and Ho. Psychological Science 25: 7-29. [CrossRef]

Czyżowska, Dorota, and Ewa Gurba. 2016. Poczucie koherencji a religijność i sposób konstruowania tożsamości osobistej w okresie wyłaniającej się dorosłości [Sense of Coherence, Religiosity and the Way of Constructing Personal Identity in the Period of Emerging Adulthood]. Psychologia Rozwojowa 20: 59-71. [CrossRef]

Czyżowska, Dorota, and Kamila Mikołajewska. 2012. Religijność a rozwój rozumowania moralnego w okresie adolescencji [Religiosity and the Development of Moral Reasoning in the Adolescence. Psychologia Rozwojowa 17: 55-70. [CrossRef]

Czyżowska, Dorota, and Kamila Mikołajewska. 2014. Religiosity and Young People's Construction of Personal Identity. Roczniki Psychologiczne/Annals of Psychology 17: 131-54.

Dezutter, Jessie, Amy Wachholtz, and Jozef Corveleyn. 2011. Prayer and Pain: The Mediating Role of Positive Re-Appraisal. Journal of Behavioral Medicine 34: 542-49. [CrossRef] [PubMed]

Drwal, R. Łukasz, Piotr Brzozowski, and Piotr Oleś. 1995. Adaptacja Kwestionariuszy Osobowości: Wybrane Zagadnienia i Techniki [Adaptation of Personality Questionnaires: Selected Issues and Techniques]. Warsaw: Wydawnictwo Naukowe PWN.

Franczak, Kazimierz. 2009. Osobowościowe korelaty wybranych form religijności [Personality Correlates of Selected Forms of Religiosity]. In Osobowość i religia [Personality and Religion]. Edited by Henryk Gasiul and Emilia Wrocławska-Warchala. Warszawa: Wydawnictwo UKSW, pp. 262-79.

Franczak, Kazimierz. 2012. Udział cech osobowościowych i form religijności w radzeniu sobie ze stresem. Badania empiryczne policjantów [Personality Traits and Religiosity in Coping with Stress. Empirical Research of Policemen]. Resocjalizacja Polska 3: 443-58.

Freud, Zygmunt. 2009. The Future of an Illusion. New York: Classic House. First published 1927. 
Goldberg, David P., and Paul Williams. 2001. Podręcznik dla użytkowników Kwestionariusza Ogólnego Stanu Zdrowia [Handbook for Users of the General Health Questionnaire]. In Ocena zdrowia psychicznego na podstawie badań kwestionariuszami Davida Goldberga: Podręcznik dla użytkowników Kwestionariuszy GHQ-12 $i$ GHQ-28 [Mental Health Assessment Based on Research with David Goldberg Questionnaires: Handbook for Users of the GHQ-12 and GHQ-28 Questionnaires]. Edited by Zofia Makowska and Dorota Merecz. Łódź: Instytut Medycyny Pracy im. Prof. J. Nofera, pp. 1-190.

Goździewicz-Rostankowska, Agata, Beata Zarzycka, and Anna Tychmanowicz. 2018. Centralność religijności i przekonania postkrytyczne a otwartość na karierę międzynarodową studentów [Centrality of Religiosity and Post-Critical Beliefs and Openness to the International Career of Students]. Annales Universitatis Mariae Curie-Skłodowska, sectio J, Paedagogia-Psychologia 31: 149-68. [CrossRef]

Hambleton, Ronald K. 2001. The next Generation of the ITC Test Translation and Adaptation Guidelines. European Journal of Psychological Assessment 17: 164-72. [CrossRef]

Händel, Katarzyna. 2017. Religiosity and Styles of Defense to Perception of Oneself, Other and Time. Studia Paradyskie 27: 295-316.

Huber, Stefan. 2003. Zentralität und Inhalt: ein neues multidimensionales Messmodell der Religiosität [Centrality and Content: A New Multidimensional Measurement Model of Religiosity]. Opladen: Leske + Budrich.

Huber, Stefan. 2004. Are Religious Beliefs Relevant in Daily Life? Paper presented at the Conference of The International Society for Empirical Research in Theology_-ISERT Religious Praxis and de-Institutionalized Religion, Bielefeld, Germany, April 22.

Huber, Stefan. 2006. The Structure-of-Religiosity-Test (S-R-T). A Comprehensive Instrument for Systematic Research in the Field of Religion. Paper presented at the 2006 Congress of the International Association for the Psychology of Religion, Leuven, Belgia, August 27-31.

Huber, Stefan. 2007. Are Religious Beliefs Relevant in Daily Life? In Religion Inside and Outside Traditional Institutions. Edited by Heinz Streib. Leiden and Boston: Brill, pp. 211-30.

Huber, Stefan. 2008a. Der Religiositäts-Struktur-Test (RST). Systematik und Operationale Konstrukte. In Individualisierung und die Pluralen Ausprägungsformen des Religiösen. Studien zu Religion und Kultur. Edited by Wilhelm Gräb and Lars Charbonnier. Münster: Lit-Verlag, pp. 109-43.

Huber, Stefan. 2008b. Kerndimensionen, Zentralität und Inhalt. Ein Interdisziplinäres Modell der Religiosität. Journal für Psychologie 16: 1-17. [CrossRef]

Huber, Stefan. 2009. Religion Monitor 2008: Structuring Principles, Operational Constructs, Interpretive Strategies. Gütersloh: Verlag Bertelsmann Stiftung.

Huber, Stefan, and Odilo W. Huber. 2012. The Centrality of Religiosity Scale (CRS). Religions 3: 710-24. [CrossRef]

Huber, Stefan, and Matthias Richard. 2010. The Inventory of Emotions towards God (EtG): Psychological Valences and Theological Issues. Review of Religious Research 52: 21-40.

Huber, Stefan, Matthias Allemand, and Odilo W. Huber. 2011. The Relation between Forgiveness by God and Human Forgivingness. The Centrality of the Religiosity Makes the Difference. Archive for the Psychology of Religion 33: 115-34. [CrossRef]

Hutsebaut, Dirk. 1980. Belief as Lived Relations. Psychologica Belgica 20: 33-47.

Kelly, George A. 1955. A Theory of Personality: The Psychology of Personal Constructs. New York: W.W Norton \& Co.

Krasiczyńska, Barbara. 2010. Psychospołeczne korelaty zespołu wypalenia zawodowego u nauczycieli Szkół Specjalnych [Psychosocial Correlates of the Professional Burnout Syndrome in Teachers of Special Schools]. Ph.D. thesis, The John Paul II Catholic University of Lublin, Lublin, Poland.

Krok, Dariusz. 2007. Myślenie przesądne a religijne funkcjonowanie osób [Superstitious Thinking and Religious Functioning]. Polskie Forum Psychologiczne 12: 93-112.

Krok, Dariusz. 2009a. Religijność a jakość życia w perspektywie mediatorów psychospołecznych [Religiosity and Quality of Life in the Perspective of Psychosocial Mediators]. Opole: Redakcja Wydawnictw Wydziału Teologicznego Uniwersytetu Opolskiego.

Krok, Dariusz. 2009b. Strukturalne powiązania religijności i duchowości w kontekście czynników osobowościowych [Structural Connections of Religiosity and Spirituality in the Context of Personality Factors]. In Osobowość i religia [Personality and Religion]. Edited by Henryk Gasiul and Emilia Wrocławska-Warchala. Warszawa: Wydawnictwo UKSW, pp. 280-99.

Krok, Dariusz. 2010. System wartości a poznawcze i społeczne wymiary religijności [The System of Values and the Cognitive and Social Dimensions of Religiosity]. Roczniki Psychologiczne/ Annals of Psychology 13: 161-82. 
Krok, Dariusz. 2011. Związek autorytaryzmu z zaangażowaniem religijnym i religijnymi stylami poznawczymi [The Relationship of Authoritarianism with Religious Involvement and Religious Cognitive Styles]. Polskie Forum Psychologiczne XVI: 123-40.

Krok, Dariusz. 2014. Religiousness and Social Support as Predictive Factors for Mental Health Outcomes. Archives of Psychiatry and Psychotherapy 16: 65-76. [CrossRef]

Krok, Dariusz. 2016a. Examining the Role of Religion in a Family Setting: Religious Attitudes and Quality of Life among Parents and Their Adolescent Children. Journal of Family Studies 24: 203-18. [CrossRef]

Krok, Dariusz. 2016b. Współzależność religijności z poczuciem sensu życia i nadzieją w okresie późnej adolescencji [Interdependence of Religiosity with a Sense of Meaning in Life and Hope in late Adolescence]. Psychologia Rozwojowa 21: 65-76. [CrossRef]

Krok, Dariusz, and Anna Żak. 2007. Zależności między religijnością i prawicowym autorytaryzmem wśród młodzieży akademickiej [Relationships between Religiosity and Right-Wing Authoritarianism among Academic Youth]. Studia Teologiczno-Historyczne Ślaska Opolskiego 2: 353-74.

Krupa, Małgorzata. 2015. Percepcja postaw rodzicielskich a centralność religijności osób w wieku dorastania [Perception of Parental Attitudes and the Centrality of Religiosity among Adolescents]. Master's thesis, Wyższa Szkoła Biznesu-National-Louis University, Nowy Sacz, Poland.

Luyten, Patrick, Jozef Corveleyn, and Johnny R. J. Fontaine. 1998. The Relationship between Religiosity and Mental Health: Distinguishing between Shame and Guilt. Mental Health, Religion E Culture 1: 165-84. [CrossRef]

Łowicki, Paweł, and Marcin Zajenkowski. 2019. Empathy and Exposure to Credible Religious Acts during Childhood Independently Predict Religiosity. The International Journal for the Psychology of Religion 29: 1-14. [CrossRef]

Łowicki, Paweł, Joanna Witowska, Marcin Zajenkowski, and Maciej Stolarski. 2018. Time to Believe: Disentangling the Complex Associations between Time Perspective and Religiosity. Personality and Individual Differences 134: 97-106. [CrossRef]

Matys, Wiesław, and Rafał P. Bartczuk. 2011. Kwestionariusz Więzi z Bogiem [Questionnaire of Relationship with God]. In Psychologiczny pomiar religijności [Psychological Measurement of Religiosity]. Edited by Marek Jarosz. Lublin: Towarzystwo Naukowe KUL, pp. 131-52.

McCrae, Robert R., and Paul T. Costa. 1996. Toward a New Generation of Personality Theories: Theoretical Contexts for the Five-Factor Model. In The Five-Factor Model of Personality. Theoretical Perspectives. Edited by J. S. Wiggins. New York and London: The Guilford Press, pp. 51-87.

Muggeo, Vito M. R. 2003. Estimating Regression Models with Unknown Break-Points. Statistics in Medicine 22: 3055-71. [CrossRef]

Muggeo, Vito M. R. 2008. Segmented: An R Package to Fit Regression Models with Broken-Line Relationships. $R$ News 8: 20-25.

Muggeo, Vito M. R. 2016. Testing with a Nuisance Parameter Present Only under the Alternative: A Score-Based Approach with Application to Segmented Modelling. Journal of Statistical Computation and Simulation 86: 3059-67. [CrossRef]

Muggeo, Vito M. R. 2017. Interval Estimation for the Breakpoint in Segmented Regression: A Smoothed Score-Based Approach. Australian \& New Zealand Journal of Statistics 59: 311-22. [CrossRef]

Nowosielski, Mirosław, and Rafał P. Bartczuk. 2011. Skala Kryzysu Religijnego W. Prężyny [The Scale of the Religious Crisis of W. Prezyna]. In Psychologiczny pomiar religijności [Psychological Measurement of Religiosity]. Edited by Marek Jarosz. Lublin: Towarzystwo Naukowe KUL, pp. 73-88.

Nowosielski, Mirosław, and Rafał P. Bartczuk. 2017. A Structural Analysis of Deconversion Processes in Adolescence: The Construction of the Adolescent Deconversion Scale. Roczniki Psychologiczne/Annals of Psychology 20: 167-90. [CrossRef]

Paloutzian, Raymond F., Sebastian Murken, Heinz Streib, and Sussan Rößler-Namini. 2013. Conversion, Deconversion, and Transformation: A Multilevel Interdisciplinary View. In Handbook of the Psychology of Religion and Spirituality, 2nd ed. New York: Guilford Press, pp. 399-421.

Rybarski, Radosław. 2019. Religijność i lęk przed śmiercią a jakość życia osób z rozpoznaną choroba nowotworowa [Religiosity, Death Anxiety and Quality of Life among People Diagnosed with Cancer]. Ph.D. thesis, The John Paul II Catholic University of Lublin, Lublin, Poland. 
Rydz, Elżbieta, and Anna Wieradzka-Pilarczyk. 2018. Religious Identity Status and Readiness for Interreligious Dialogue in Youth. Developmental Analysis. Journal for Perspectives of Economic Political and Social Integration 23: 69-90. [CrossRef]

Rydz, Elżbieta, and Beata Zarzycka. 2008. Kompetencje społeczne a religijność osób w okresie młodej dorosłości [Social competences and religiosity of people in young adulthood]. In Z Zagadnień Psychologii Rozwoju Człowieka. Edited by Elżbieta Rydz and Dagmara Musiał. Lublin: Towarzystwo Naukowe KUL, vol. II, pp. 65-82.

Rydz, Elżbieta, Rafał P. Bartczuk, Beata Zarzycka, and Anna Wieradzka-Pilarczyk. 2019. Readiness to Engage in Interreligious Dialogue Test-Internal Structure, Reliability and Validity. Mental Health, Religion E Culture, 1-19. [CrossRef]

Stark, Rodney, and Charles Y. Glock. 1970. American Piety: The Nature of Religious Commitment. Berkeley, Los Angeles and London: University of California Press.

Szymołon, Jerzy, and Rafał P. Bartczuk. 2011. Skala Centralności Postawy Religijnej W. Prężyny [Centrality of Religious Attitude Scale by W. Prężyna]. In Psychologiczny pomiar religijności [Psychological Measurement of Religiosity]. Edited by Marek Jarosz. Lublin: Towarzystwo Naukowe KUL, pp. 25-44.

Śliwak, Jacek, and Rafał P. Bartczuk. 2011a. Skala Intensywności Postawy Religijnej W. Prężyny [W. Prężyna's Religious Attitude Scale]. In Psychologiczny pomiar religijności [Psychological Measurement of Religiosity]. Edited by Marek Jarosz. Lublin: Towarzystwo Naukowe KUL, pp. 45-72.

Śliwak, Jacek, and Rafał P. Bartczuk. 2011b. Skala Relacji Religijnych—Przeżywane Relacje do Boga D. Hutsebauta [Scale of Religious Relationships—Lived Relations with God by D. Hutsebaut]. In Psychologiczny pomiar religijności [Psychological Measurement of Religiosity]. Edited by Marek Jarosz. Lublin: Towarzystwo Naukowe KUL, pp. 171-200.

Śliwak, Jacek, Beata Zarzycka, and Aldona Karnówka. 2009. Zentralität Religiöser Konstruktsysteme-Moderator der Beziehungen zwischen Religiosität und Fünf-Faktoren-Modell [Centrality of Religious Construct Systems-The Moderator of the Relationships between Religiosity and Five-Factor Model]. Paper presented at the 2009 Congress of the International Association for the Psychology of Religion, Austria, Vienna, August 23-27.

Tatala, Małgorzata, Czesław Walesa, and Elżbieta Rydz. 2017. Structure and Level of Religiosity Test. Polish Psychological Bulletin 48: 20-27. [CrossRef]

Turska-Kawa, Agnieszka. 2018. Centrality of Religiosity versus Civic Involvement. The Case of Poland. Communist and Post-Communist Studies 51: 39-48. [CrossRef]

Tychmanowicz, Anna, Agata Goździewicz-Rostankowska, and Beata Zarzycka. 2018. Związki sprawczości i wspólnotowości z wybranymi miarami religijności u polskich katolików [Relations between Agency and Community with Selected Measures of Religiosity in Polish Catholics]. Studia Psychologica 1: 5-22. [CrossRef]

Zarzycka, Beata. 2007. Skala Centralności Religijności Stefana Hubera [The Polish Version of S. Huber's Centrality of Religiosity Scale]. Roczniki Psychologiczne] 10: 133-57.

Zarzycka, Beata. 2011. Polska Adaptacja Skali Centralności Religijności S. Hubera [Polish Adaptation of Huber's Centrality of Religiosity Scale]. In Psychologiczny pomiar religijności [Psychological Measurement of Religiosity]. Edited by Marek Jarosz. Lublin: Towarzystwo Naukowe KUL, pp. 231-61.

Zarzycka, Beata. 2016. Prevalence and social-cognitive predictors of anger toward God in a Polish sample. The International Journal for the Psychology of Religion 26: 225-239. [CrossRef]

Zarzycka, Beata. 2017. Zmagania religijne: uwarunkowania i funkcje [Religious Struggles: Determinants and Functions]. Lublin: Wydawnictwo KUL.

Zarzycka, Beata, and Rafał P. Bartczuk. 2011. Polska adaptacja Skali Emocji do Boga (EtG) S. Hubera [Polish Adaptation of the Emotions toward God Scale (EtG) by S. Huber]. In Psychologiczny pomiar religijności [Psychological Measurement of Religiosity]. Edited by Marek Jarosz. Lublin: Towarzystwo Naukowe KUL, pp. 263-92.

Zarzycka, Beata, and Elżbieta Rydz. 2011. The Selective Relationship between Religious Dimensions and Social Desirability among Polish Students. Mental Health, Religion \& Culture 14: 411-22.

Zarzycka, Beata, and Elżbieta Rydz. 2014. Centrality of Religiosity and Sense of Coherence: A Cross-Sectional Study with Polish Young, Middle and Late Adults. International Journal of Social Science Studies 2: 126-36. [CrossRef] 
Zarzycka, Beata, Anna Tychmanowicz, and Agata Goździewicz-Rostankowska. 2016. The Interplay between Religiosity and Horizontal and Vertical Individualism-Collectivism among Polish Catholic Students. Polish Psychological Bulletin 47: 383-93. [CrossRef]

Zarzycka, Beata, Paweł Ciszek, and Karolina Rykowska. 2018. The Polish Adaptation of the Religious and Spiritual Struggles Scale: Factorial Structure and Psychometric Properties. Roczniki Psychologiczne/Annals of Psychology 21: 255-78. [CrossRef]

Zarzycka, Beata, Tomasz Liszewski, and Marek Marzel. 2019. Religion and Behavioral Procrastination: Mediating Effects of Locus of Control and Content of Prayer. Current Psychology. [CrossRef]

Żurek, Anita. 2015. Style wychowania doświadczane w dzieciństwie jako korelaty religijności osób dorosłych. Pilotażowe badania empiryczne wśród rodziców dzieci przygotowujących się do sakramentu Eucharystii [Upbringing Styles Experienced in Childhood as Correlates of Adult Religiosity. Pilot Empirical Research among Parents of Children Preparing for the Sacrament of the Eucharist]. Studia Paradyskie 25: 229-46.

(C) 2020 by the authors. Licensee MDPI, Basel, Switzerland. This article is an open access article distributed under the terms and conditions of the Creative Commons Attribution (CC BY) license (http://creativecommons.org/licenses/by/4.0/). 